\title{
Panduan Aneuk Meutuah untuk Meningkatkan Regulasi Emosi Anak Usia 3 - 4 Tahun
}

\author{
Setio Budi Raharjo ${ }^{\circledR}$, Baharuddin ${ }^{1}$ \\ Keperawatan, Politeknik Kesehatan Kementerian Kesehatan Aceh, Indonesia( ${ }^{(1)}$ \\ DOI: $10.31004 /$ obsesi.v6i2.1552
}

\begin{abstract}
Abstrak
Perkembangan emosi menjadi aspek penting pada anak usia 3 - 4 tahun. Ketidaksesuaian emosi antara orang tua dan anak sering ditemukan dalam aktifitas sehari-hari. Orang tua dapat meningkatkan kompetensi latihan emosi parenting dengan Panduan Aneuk Meutuah. Penelitian ini bertujuan untuk mengetahui efektifitas panduan Aneuk Meutuah untuk meningkatkan Latihan emosi parenting terkait regulasi emosi anak usia 3 - 4 tahun. Jenis penelitian ini adalah Quasi Eksperimental dengan desain penelitian Nonequivalent Control Group Design. Penelitian ini dilakukan di TK Bungong Reudeup (Kelompok percobaan) dan TK Tuanku Abdul Aziz(Kelompok kontrol) pada anak kelompok B. Sampel diambil secara nonrandom. Data dikumpulkan melalui tes, observasi dan dokumentasi, kemudian dianalisis menggunakan analisis statistik dengan uji Anova. Hasil penelitian membuktikan bahwa Panduan Aneuk Meutuah berpengaruh terhadap latihan emosi parenting terkait regulasi emosi anak usia 3-4 tahun. Dengan demikian, penulis simpulkan bahwa efektivitas Panduan Aneuk Meutuah berpengaruh secara signifikan untuk meningkatkan latihan emosi parenting terkait regulasi emosi anak usia 3-4 tahun.
\end{abstract}

Kata Kunci: panduan aneuk meutuah; latihan emosi parenting; anak usia 3- 4 tahun

\begin{abstract}
Emotional development becomes an important aspect in children aged 3-4 years. Emotional discrepancies between parents and children are often found in daily activities. Parents can improve the competence of parenting emotion training with Aneuk Meutuah Guide. This study aims to determine the effectiveness of Aneuk Meutuah's guide to improve parenting emotion training related to emotional regulation of children aged 3 - 4 years. This type of research is a quasi-experimental research design with Nonequivalent Control Group Design. This research was conducted in Bungong Reudeup Kindergarten (experimental group) and Tuanku Abdul Aziz Kindergarten (control group) in group B children. Samples were taken non-randomly. Data were collected through tests, observations and documentation, then analyzed using statistical analysis with the Anova test. The results of the study prove that the Aneuk Meutuah Guide has an effect on parenting emotion training related to emotional regulation of children aged 3-4 years. Thus, the authors conclude that the effectiveness of the Aneuk Meutuah Guide has a significant effect on increasing parenting emotion training related to emotional regulation of children aged 3-4 years.
\end{abstract}

Keywords: Aneuk Meutuah Guide, Parenting Emotion Coaching, Children aged 3-4 years

Copyright (c) 2021 Setio Budi Raharjo, Baharuddin

$\triangle$ Corresponding author :

Email Address : setio_budiraharjo@yahoo.co.id (Aceh, Indonesia)

Received 12 February 2021, Accepted 13 July 2021, Published 18 July 2021 


\section{PENDAHULUAN}

Pendidikan prasekolah memiliki dampak positif bagi perkembangan kognitif dan sosial emosional anak usia dini. Usia 3 - 4 tahun merupakan suatu periode waktu pertumbuhan dan perkembangan penting pada individu yang dapat dijadikan landasan agar anak dapat berkembang secara optimal. Berbagai stimulasi (rangsangan) eksternal sangat membantu anak dalam bertindak dan mengekspresikan emosi secara spontan (Graziano et al.,

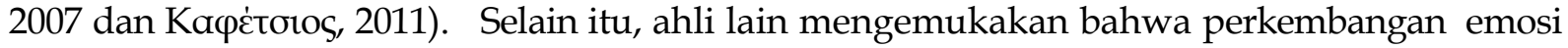
anak akan lebih optimal bila diberikan rangsangan sensorik langsung (Achenbach, 1987). Oleh karena itu perlu satu upaya yang memberikan kontribusi positif untuk terlibat dalam proses perkembangan emosi anak usia dini $3-4$ tahun. Orang tua sebagai orang pertama dapat membantu anak usia 3-4 tahun untuk meningkatkan regulasi emosinya dimana mereka masih sangat tergantung dengan lingkungan belajar di rumah.

Orang tua sebagai orang terdekat dengan anak dapat meningkatkan regulasi anak melalui bina hubungan saling percaya hingga terbentuk jalinan ikatan emosional yang kuat dan harmonis. Hal tersebut diperkuat oleh Cassidy(1994) yang mengemukakan bahwa pentingnya hubungan orang tua-anak dalam perkembangan emosi. Didukung oleh, Gross (2014) yang menyatakan bahwa orang tua sebagai pengatur eksternal emosi anak dapat menjadi model pengalaman awal anak dalam regulasi emosi. Orang tua dituntut menjadi panutan mengingat kompetensi orang tua memberi pengaruh yang beragam bagi anak dalam menafsirkan dan menilai perasaan mereka serta mengelola tuntutan emosi mereka.

Kompetensi orang tua terkait pengaturan emosi dapat ditingkatkan melalui latihan emosi parenting. Latihan emosi parenting secara sistematis mengajarkan mengenal emosi, merespon positif, bersikap empati, membantu anak melabel emosi, dan menemukan solusi. Metode ini dapat digunakan orang tua pada sa'at kejadian berlangsung dengan mengelola emosi dan memberi bimbingan pada anak usia dini. Hal tersebut sesuai hasil penelitian yang menyatakan bahwa emosi dan pengalaman awal emosional dibentuk ketika orang tua menjalankan perannya (Santrok, 2002). Selain itu juga, peneliti lain mengemukakan bahwa ekspresi emosional anak usia dini sangat terkait dengan perilaku ekspresif orang tua mereka sendiri (Nelson \& others, 2012). Adapun salah satu kreteria adanya kesesuaian emosi antara orang tua dan anak usia dini adalah anak patuh dan komitmen terhadap perintah orang tua mereka.

Pada kenyataannya, beberapa permasalahan selalu ada dan menjadikan semua harapan tidak berjalan dengan sempurna. Orang tua sebagai role model mengalami beberapa hambatan dalam mensosialisasi emosi gaya ekspresif terkait aspek ekspresi emosi dan mengatur emosi anak usia 3-4 tahun. Keadaan tersebut seusai hasil penelitian yang mengemukakan bahwa sosialisasi emosi dapat meningkatkan kemampuan emosi orang tua untuk menafsirkan makna emosi dalam berbagai situasi (Eisenberg etal.,1998). Selain itu, sebagian besar orang tua memiliki pengetahuan yang rendah tentang sosialisasi emosi terutama aspek pemahaman, pengalaman, ekspresi, dan regulasi emosi anak. Selanjutnya, data hasil observasi menunjukkan bahwa anak anak usia 3-4 tahun sering mengalami ketidakseimbangan emosi. Kedua aspek tersebut akan berdampak pada penampakan ekspresi emosi sehari- hari anak yang diekspresikan, yaitu ketidaksesuaian refleksi emosi antara orang tua dengan anak usia 3-4 tahun.

Fokus masalah penulisan adalah pada reaksi emosi orang tua terhadap pengalaman dan ekspresi emosi anak usia 3-4 tahun. Reaksi emosi orang tua terhadap ekspresi emosi anak adalah contoh yang sangat baik tentang cara orang tua dapat secara langsung mensosialisasikan reaksi emosi yang berhubungan dengan ekspresi emosi anak. Sebagai contoh, seorang anak berusia 3 tahun mungkin merasa malu ketika orang tuanya berkata, "Kamu seharusnya merasa tidak enak karena menggigit jari tangan adikmu." Dalam fenomena tersebut, orang tua lebih banyak mengekspresikan emosi positif dan lebih sedikit mengekspresikan emosi negatif. Didukung hasil observasi, ekspresi emosi anak lebih banyak menggunakan kata-kata emosi positif selama interaksi orang tua dengan anak daripada orang 
tua yang menggunakan sedikit mengekspresikan emosi positif. Hal tersebut diperkuat oleh peneliti lain bahwa ada hubungan antara ekspresi emosi positif ibu dan keterlibatan emosi positif anak, lebih kuat untuk anak-anak dengan tingkat emosi negatif rendah, dibandingkan mereka dengan tingkat emosi negatif rata-rata atau tingkat emosi negatif tinggi (Q. Wu et al., 2016).

Latihan emosi pareting dengan panduan Aneuk Meutuah dapat memberikan kontribusi yang besar dalam pengembangan gaya ekspresif emosi orang tua diantaranya pemahaman tentang emosi diri sendiri dan orang lain, menampilkan emosi yang sesuai dengan situasi dan budaya, dan perilaku yang diturunkan secara emosional yang dapat diterima secara sosial. Latihan emosi parenting mengintegrasikan tehnik dengan pendekatan intervensi berbasis kesadaran diri. Panduan Aneuk Meutuah memberi pemahaman dan petunjuk ketrampilan reaksi emosi positif pada orang tua. Hasil penelitian mengemukakan bahwa pemahaman orang tua tentang mekanisme latihan emosi menunjukkan efektifitas dalam menfasilitasi adaptasi ketrampilan praktik dalam versi panjang kemudian dipersingkat dalam waktu sangat singkat (3 detik sampai dengan 3 menit) (Eisenberg etal.,1998). Selain itu, panduan Aneuk Meutuah memberikan urutan ketrampilan dalam memaknai ekspresif emosi positif orang tua terkait regulasi emosi anak usia 3-4 tahun, contohnya untuk mengatasi anak yang tidak percaya diri, orang tua dapat mengatakan" Bunda suka gambar-gambarmu, warna yang kamu pakai sangat bagus" dengan menunjukan sikap empati dan komunikasi efektif. Panduan Aneuk Meutuah juga memiliki kegunaan untuk mengaktifkan perilaku dengan sengaja karena mengingat pentingnya mengatur reaski emosional dalam situasi tertentu, misalnya anak pemalu selalu menolak ajakan orang lain, maka orang tua segera bersikap empati dengan membantu cara berkenalan dengan teman sebaya.

Pada penelitian ini, penggunaan panduan Aneuk Meutuah bertujuan untuk lebih meningkatkan latihan emosi parenting, khususnya kemampuan mengenal emosi, merespon positif, bersikap empati, membantu anak melabel emosi, dan menemukan solusi. Hal baru dalam penelitian ini yaitu peneliti akan lebih menekankan pada kegiatan latihan emosi parenting yang dirancang dengan kegiatan rutin memaknai kata "Aneuk Meutuah" yang segera menyadarkan orang tua dalam perannya sebagai role model dan pengatur ekstrenal emosi anak. Pemodifikasian pada latihan emosi parenting ini juga disesuaikan dengan personality anak, pendidikan orang tua, budaya keluarga, dan hubungan komunikasi orang tua dengan anak usia 3-4 tahun. Selain itu, panduan tersebut dapat meningkatkan gaya eksrepsif emosi orang tua dan pemodifikasian latihan emosi parenting ini juga akan meningkatkan refleksi emosi, komunikasi interpersonal, dan kemandirian anak usia anak 3-4 tahun yang belum ada pada hasil penelitian terdahulu.

Berdasarkan latar belakang di atas menggugah peneliti untuk menggunakan panduan Aneuk Metuah untuk meningkatkan latihan emosi parenting terkait regulasi emosi anak usi 34 tahun. Efektivitas dalam penggunaan panduan Aneuk Meutuah ini dapat menarik perhatian dan memberikan kesan serta cara pembelajaran khusus terhadap anak usia 3-4 tahun.

Dengan memperhatikan beberapa tinjauan teori dan fenomena yang ada maka rumusan penelitian dijabarkan ke dalam pertanyaan berikut; (1) Bagaimana pemahaman orang tua tentang panduan Aneuk Meutuah untuk meningkatkan latihan emosi parenting terkait emosi anak usia 3-4 tahun? (2) Apakah Panduan Aneuk Meutuah efektif untuk meningkatkan latihan emosi parenting terkait emosi anak usia 3-4 tahun?

\section{METODOLOGI}

Penelitian ini adalah penelitian eksperimen semu (quasi experiment) dengan rancangan non-equivalen control group pre-test-post-test design. Penelitian dilaksanakan pada PAUD di Wilayah kerja Puskesmas Kecamatan Baitussalam Kabupaten Aceh Besar tahun 2020 yang terdiri dari 30 orang tua yang memiliki anak usia 3-4 tahun. Penelitian menggunakan dua TK/PAUD terpisah (masing-masing 15 orang tua), yaitu orang tua yang memiliki anak usia 
3-4 tahun, PAUD Bungong Reudeup sebagai kelas eksperimen (diterapkan Latihan emosi parenting dengan panduan Aneuk Meutuah) dan TK/PAUD Tuanku Abdul Aziz sebagai kelas kontrol (diterapkan latihan emosi parenting dengan modul standar parenting)(Kemdikbud, 2020). Jumlah sampel dalam penelitian ini ditetapkan sebanyak 30 orang tua yang memiliki anak usia 3-4 tahun. Sampel diambil secara nonrandom. Setiap TK/PAUD didampingi oleh semua orang tua. Pelaksanaan kegiatan penelitian, orang tua pada kelompok eksperimen dan kelompok kontrol dilaksanakan pretes terkait panduan Aneuk Meutuah dalam latihan emosi parenting untuk meningkatkan regulasi emosi anak usia 3-4 tahun. Pada kelompok kontrol diterapkan latihan emosi parenting dengan modul parenting kemdikbud(Mengelola Emosi Orang Tua Dalam Proses Pengasuhan) dan pada kelompok eksperimen diterapkan latihan emosi parenting dengan Panduan Aneuk Meutuah. Tahapan latihan emosi parenting dengan panduan Aneuk Meutuah dimulai dengan penjelaskan tujuan panduan Aneuk Meutuah dalam latihan emosi parenting, menjelaskan capaian kegiatan latihan emosi parenting melalui buku kerja, dan memotivasi orang tua agar terlibat pada aktivitas regulasi emosi anak usia 3-4 tahun melalui kartu emosi. Selain itu, orang tua berupaya mengenalkan jenis emosi, menyusun emosi dan bagaimana berekspresi emosi. Membantu anak usia 3-4 tahun melakukan ekspresi emosi melalui kartu emosi dan menurunnya disregulasi emosi. Penelitian ini dilakukan pada PAUD di wilayah Puskesmas Kecamatan Baitussalam Aceh Besar mulai minggu keempat bulan Juli sampai dengan minggu keempat bulan November 2020.

Sementara itu, langkah-langkah latihan emosi parenting dengan modul standar parenting adalah guru atau orang tua yang memiliki anak usia 3-4 menjelaskan materi sesuai dengan urutan materi dalam modul standar parenting yang digunakan sebagai pengangan orang tua. Orang tua memberikan contoh berekspresi dan menpraktikan untuk memperjelas materi dalam modul. Kemudian orang tua meminta anak usia 3-4 tahun untuk menirukan serta berespon sesuai yang terdapat dalam modul. Kegiatan penelitian diakhiri dengan posttes pada kelompok eksperimen dan pada kelompok kontrol.

Instrumen-instrumen yang digunakan dalam penelitian ini adalah tes kemampuan latihan emosi parenting dan tes pengetahuan atau kognitif. Tes kemampuan latihan emosi parenting menggunakan buku kerja yang berfungsi untuk mengukur capaian latihan emosi parenting yang menyangkut aspek mengenal emosi, menyusun dan berekspresi emosi, serta pernyataan latihan emosi parenting (Lihat tabel 1)

Tabel 1. Instrumen Capaian Latihan emosi parenting

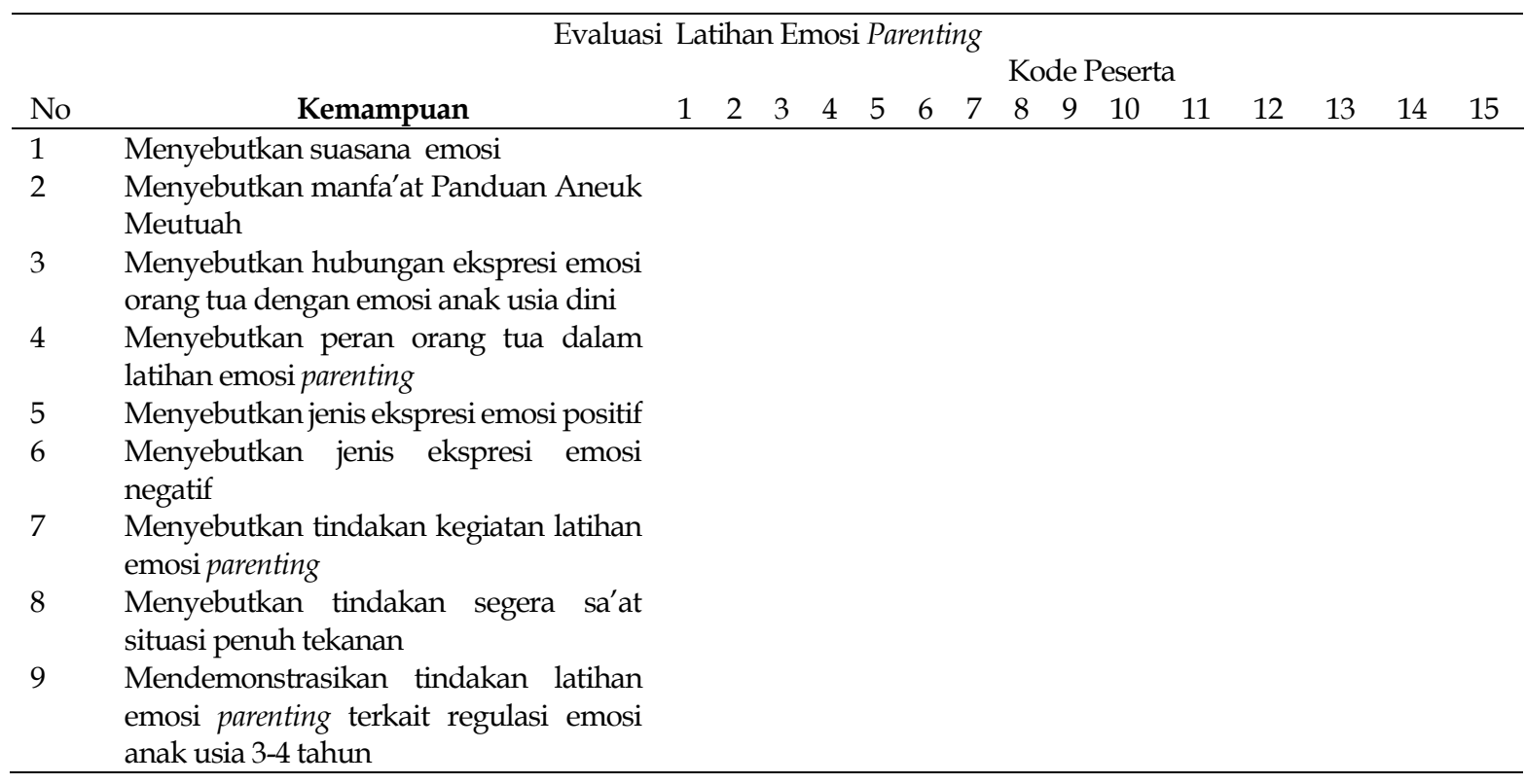


DOI: 10.31004/obsesi.v6i2.1552

\begin{tabular}{|c|c|c|c|c|}
\hline Indikator & Baik Sekali & Baik & Cukup & Perlu Berlatihan lagi \\
\hline \multirow[t]{2}{*}{$\begin{array}{l}\text { Mengenal } \\
\text { jenis emosi }\end{array}$} & $\begin{array}{l}\text { Orang tua dapat } \\
\text { menyebutkan } 4 \text { jenis } \\
\text { emosi positif dan } 4 \\
\text { jenis emosi negatif } \\
\text { dengan benar }\end{array}$ & $\begin{array}{l}\text { Orang tua hanya } \\
\text { mampu } \\
\text { menyebutkan } 2 \\
\text { jenis emosi positif } \\
\text { dan } 2 \text { jenis emosi }\end{array}$ & $\begin{array}{l}\text { Orang tua hanya } \\
\text { mampu } \\
\text { menyebutkan salah } \\
\text { satu jenis kelompok } \\
\text { emosi } 4 \text { jenis emosi } \\
\text { positif atau } 4 \text { emosi } \\
\text { negatif }\end{array}$ & $\begin{array}{l}\text { Orang tua belum } \\
\text { dapat menyebutkan } 4 \\
\text { jenis emosi positif } \\
\text { dan } 4 \text { jenis emosi } \\
\text { negatif dengan benar }\end{array}$ \\
\hline & 4 & 3 & 2 & 1 \\
\hline \multirow[t]{2}{*}{$\begin{array}{l}\text { Mengontrol } \\
\text { emosi }\end{array}$} & $\begin{array}{l}\text { Orang tua dapat } \\
\text { menyebutkan } \\
\text { langkah awal } \\
\text { tindakan segera sa'at } \\
\text { situasi penuh tekanan } \\
\text { dalam waktu singkat }\end{array}$ & $\begin{array}{l}\text { Orang tua dapat } \\
\text { menyebutkan } \\
\text { langkah awal } \\
\text { tindakan segera } \\
\text { sa'at situasi penuh } \\
\text { tekanan, namun } \\
\text { dalam waktu } 5 \\
\text { sampai } 10 \text { menit }\end{array}$ & $\begin{array}{l}\text { Orang tua dapat } \\
\text { menyebutkan } \\
\text { langkah awal } \\
\text { tindakan segera sa'at } \\
\text { situasi penuh tekanan } \\
\text {, namun dalam waktu } \\
\text { lebih dari } 10 \text { menit }\end{array}$ & $\begin{array}{l}\text { Orang tua belum } \\
\text { dapat menyebutkan } \\
\text { langkah awal } \\
\text { tindakan segera sa'at } \\
\text { situasi penuh } \\
\text { tekanan dan tidak } \\
\text { berurutan }\end{array}$ \\
\hline & 4 & 3 & 2 & 1 \\
\hline \multirow[t]{2}{*}{$\begin{array}{l}\text { Mengelola } \\
\text { Emosi }\end{array}$} & $\begin{array}{l}\text { Orang tua dapat } \\
\text { mempraktikan latihan } \\
\text { emosi parenting } \\
\text { sesuai dengan jenis } \\
\text { ekspresi emosi yang } \\
\text { diterapkan pada anak }\end{array}$ & $\begin{array}{l}\text { Orang tua dapat } \\
\text { mempraktikan } \\
\text { latihan emosi } \\
\text { parenting, namun } \\
\text { kesulitan dalam } \\
\text { menentukan emosi }\end{array}$ & $\begin{array}{l}\text { Orang tua dapat } \\
\text { mempraktikan latihan } \\
\text { emosi parenting, } \\
\text { namum menemukan } \\
\text { hambatan dalam } \\
\text { reflesi ekspresi emosi }\end{array}$ & $\begin{array}{l}\text { Orang tua belum } \\
\text { dapat mempraktikan } \\
\text { latihan emosi } \\
\text { parenting sesuai } \\
\text { dengan jenis ekspresi } \\
\text { emosi yang } \\
\text { diterapkan pada anak } \\
\text { usia 3-4 tahun }\end{array}$ \\
\hline & 4 & 3 & 2 & 1 \\
\hline Inteprestasi & $\begin{array}{r}\text { Baik sel } \\
\text { Mean+1,5 S }\end{array}$ & $\begin{array}{c}\text { Baik } \\
\text { Mean+0,5 SD }\end{array}$ & $\begin{array}{c}\text { Cukup } \\
\text { Mean - 0,5 SD }\end{array}$ & $\begin{array}{c}\text { Kurang } \\
\text { Mean - 1,5 SD }\end{array}$ \\
\hline
\end{tabular}

Untuk mengukur kognitif orang tua digunakan tes standar latihan emosi parenting (Mashburn et al., 2008). Tes ini terdiri dari latihan sadar emosi, menetapkan emosi (verbal, ekspresi dan perilaku) dan keyakinan yang salah dalam emosi (Lihat tabel.2. dibawah).

Tabel 2 Tes Pemahaman tentang Latihan Emosi Parenting

\begin{tabular}{|c|c|c|c|c|}
\hline No. & Kemampuan & Soal & Indikator & Kategori \\
\hline 1. & Kognitif & $\begin{array}{l}\text { Pernyataan yang sesuai } \\
\text { dengan diri saya }\end{array}$ & $\begin{array}{l}\text { 1. Saya sulit mengungkapkan } \\
\text { perasaan } \\
\text { 2. Saya mudah mengungkapkan } \\
\text { perasaan) }\end{array}$ & $\begin{array}{l}\text { Baik } \\
\text { Kurang }\end{array}$ \\
\hline & & $\begin{array}{l}\text { Panduan Aneuk Meutuah } \\
\text { menambah pengetahuan } \\
\text { saya tentang latihan emosi } \\
\text { parenting }\end{array}$ & $\begin{array}{l}\text { 1. Benar } \\
\text { 2.Salah }\end{array}$ & $\begin{array}{l}\text { Baik } \\
\text { Kurang }\end{array}$ \\
\hline 2. & Afektif & $\begin{array}{l}\text { Saya menyadari bahwa ada } \\
\text { hubungan antara emosi } \\
\text { orang tua dengan regulasi } \\
\text { emosi anak }\end{array}$ & $\begin{array}{l}\text { 1. Benar } \\
\text { 2.Salah }\end{array}$ & $\begin{array}{l}\text { Baik } \\
\text { Kurang }\end{array}$ \\
\hline 3. & Perilaku & $\begin{array}{l}\text { Pernyataan yang sesuai } \\
\text { dengan diri saya }\end{array}$ & $\begin{array}{l}\text { 1.Saya merasa kurang nyaman ketika } \\
\text { kesalahan yang pernah saya } \\
\text { lakukan walaupun saya sydah } \\
\text { memperbaikinya } \\
\text { 2. Saya merasa nyaman ketika } \\
\text { kesalahan yang pernah saya } \\
\text { lakukan walaupun saya sudah } \\
\text { memperbaikinya }\end{array}$ & $\begin{array}{l}\text { Baik } \\
\text { Kurang }\end{array}$ \\
\hline
\end{tabular}


Selanjutnya, peneliti melalukan uji validitas terhadap instrumen untuk memenuhi persyaratan sebelum diberikan kepada subyek penelitian. Perhitungan validitas dibantu dengan program SPSS 16 Window. Hasil uji validitas dinyatakan semua item soal valid dengan $\mathrm{r}$ hitung $>\mathrm{r}$ tabel . Rangkuman uji validitas dapat dilihat pada tabel 3 .

Tabel 3 Rangkuman Uji Validitas instrumen tes latihan emosi parenting

\begin{tabular}{cccc}
\hline No.Item & $\mathrm{r}_{\text {hitung }}$ & $\mathrm{r}_{\text {tabel }}$ & Keterangan \\
\hline 1 & 0,693 & 0,361 & Valid \\
2 & 0,620 & 0,361 & Valid \\
3 & 0,721 & 0,361 & Valid \\
4 & 0,797 & 0,361 & Valid \\
\hline
\end{tabular}

Dari Tabel 3 menunjukan dari 4 soal tes latihan emosi parenting terkait dengan regulasi emosi anak usia 3-4 tahun dinyatakan valid dengan $\mathrm{r}$ hitung $>\mathrm{r}$ tabel . Sedangkan, hasil pengujian reliabilitas instrumen diperoleh alpha chroanbach 0,667 dengan nilai batas kritis ditetapkan sebesar 0,60 , sehingga instrumen penelitian dapat dikatakan dinyatakan reliabel, dimana alpha croanbach $0,667>0,60$.

Data kuantitatif dalam penelitian ini diperoleh dari skor pre-tes dan skor post-tes tes kemampuan aplikasi panduan Anaeuk Meutuah untuk meningkatkan latihan emosi parenting terkait regulasi emosi anak usia 3-4 tahun. Dengan ketentuan, jika orang tua memperoleh skor $\leq 50 \%$ dari skor ideal, maka orang tua digolongkan memiliki capaian gaya kognitif Field Dependent(FD) dan jika orang tua memperoleh skor $>50 \%$, maka orang tua digolongkan memiliki gaya kognitif Field Intermediate (FI)(Aubrey et al., 2000). Selanjutnya, menghitung gain ternormalisasi antara skor rata-rata pre-test dan skor rata-rata post-test. Adapun rumus N-gain ternormalisasi dapat dilihat dibawah ini:(Saputra et al., 2017 dan Hake, 1999)

$$
N-\text { gain normal ized }=\frac{\text { skor postes }- \text { skor pretes }}{\text { Skor total }- \text { skor pretes }}
$$

Uji normalitas sebaran data menggunakan statistik Kolmogorov-Smirnov test atau Shapiro-Wilk test. Uji ini dapat dilakukan dengan memanfaatkan bantuan SPSSPC 16.0 for Windows. Kriteria pengujiannya adalah data memiliki sebaran distribusi normal jika angka signifikansi yang diperoleh dari Shapiro-Wilk test lebih besar dari 0,05 dan dalam hal lain sebaran berdistribusi normal.

Uji homogenitas varians antar kelompok menggunakan Levene's Test of Equality of Error Variance. Uji ini dapat dilakukan dengan memanfaatkan bantuan SPSS-PC 16.0 for Windows. Jika signifikansi yang diperoleh $>0,05$, maka variansi setiap sampel homogen.

Untuk menguji hipotesis penelitian ini digunakan Analisis Varian (Anova) faktorial $2 \times 2$, dengan alasan bahwa variansi total semua subjek dalam suatu penelitian dapat dianalisis menjadi dua sumber, yaitu: varians antar kelompok dan varians dalam kelompok dan anava faktorial $2 \times 2$ (dua jalur) dapat digunakan untuk menguji perbedaan dua mean atau lebih.

\section{HASIL DAN PEMBAHASAN}

Pada penelitian ini, sebelum dilakukan uji hipotesis dengan menggunakan formula Anova satu jalur, maka hasil pre tes dan post test kemampuan latihan emosi parenting terlebih dahulu harus memenuhi uji prasyarat. Adapun uji prasyarat yang dilakukan adalah uji normalitas dan uji homogenitas varians. Uji normalitas dilakukan untuk mengetahui apakah sebaran frekuensi data setiap variabel berdistribusi normal atau tidak. Pengujian normalitas 
dilakukan dengan menggunakan program SPSS 16,0 for Windows, yaitu dengan menggunakan rumus Kolmogorov Smirnov, dengan kriteria: jika sig $\geq 0,05$ maka data berdistribusi normal dan jika sig $<0,05$, maka data tidak berdistribusi normal. Adapun hasil perhitungan uji normalitas disajikan pada Tabel 4 dan 5 (lihat tabel dibawah).

Tabel 4 Uji Normalitas kelompok Perlakuan One sampel Kolmogorov-Smirnov test

\begin{tabular}{llll}
\hline & & \multicolumn{1}{c}{ Pre tes } & \multicolumn{1}{c}{ Post Tes } \\
N & & \multicolumn{1}{c}{15} & \multicolumn{1}{c}{15} \\
\hline Normal Parameters $^{a}$ & Mean & 1,21 & 1,37 \\
& St Deviasi & 0,102 & 0,044 \\
Most Extreme Differences & Absolut & 0,137 & 0,162 \\
& Positive & 0,137 & 0,104 \\
& Negatif & $-0,136$ & $-0,162$ \\
Kolmogorov-Smirnov Z & & 0,530 & 0,629 \\
Asymp.Sig.(2-tailed) & & 0,941 & 0,823 \\
\hline \multicolumn{3}{c}{${ }^{a}$ Test distribution is normal }
\end{tabular}

Tabel 5 Uji Normalitas kelompok Kontrol One sampel Kolmogorov-Smirnov test

\begin{tabular}{llll}
\hline & & \multicolumn{1}{c}{ Pre tes } & \multicolumn{1}{c}{ Post Tes } \\
$\mathrm{N}$ & & \multicolumn{1}{c}{15} & \multicolumn{1}{c}{15} \\
\hline Normal Parameters $^{a}$ & Mean & 1,20 & 1,26 \\
& St Deviasi & 0,087 & 0,077 \\
Most Extreme Differences & Absolut & 0,211 & 0,168 \\
& Positive & 0,211 & 0,168 \\
Kolmogorov-Smirnov Z & Negatif & $-0,137$ & $-0,136$ \\
Asymp.Sig.(2-tailed) & & 0,815 & 0,652 \\
& & 0,519 & 0,788 \\
\hline
\end{tabular}

${ }^{a}$ Test distribution is normal

Berdasarkan hasil uji normalitas pada tabel 4 dan 5 dapat diketahui bahwa data tersebar normal untuk semua unit analisis baik pada kelompok perlakuan maupun kelompok kontrol. Hal tersebut dapat dilihat pada nilai signifikansi uji Kolmogorov-Smirnov yang menunjukkan nilai sigifikansi lebih besar dari 0,05. Dengan demikian, skor kemampuan latihan emosi parenting dapat dikatakan berdistribusi normal pada kelompok perlakukan dan kelompok kontrol.

Pengujian homogenitas dilakukan dengan menggunakan uji Levene's Test of Equality of Error Variance yang dianalisis dengan program SPSS-PC 16.0 for Windows. Data dikatakan memiliki varian yang sama, jika angka signifikansi yang diperoleh lebih besar dari 0,05. Berikut data hasil uji homogenitas varian data (Lihat tabel 6).

Tabel 6 Uji Homogenitas latihan emosi parenting dengan panduan Aneuk Meutuah Tes Homogeneity of Variances

\begin{tabular}{cccc}
\hline Levene Statistic & df1 & df2 & Sig. \\
\hline 0.187 & 1 & 28 & 0,669 \\
\hline
\end{tabular}

Berdasarkan tabel 6 menunjukkan bahwa diperoleh hasil angka signikansi sebesar 0,669 lebih besar dibandingkan angka 0,05. Hal tersebut menggambarkan bahwa data kemampuan latihan emosi parenting dengan panduan Aneuk Meutuah memiliki sebaran data yang homogen. 
Tahap selanjutnya, pengujian hipotesa menggunakan Anova dengan bantuan program SPSS-PC 16.0 for Windows. Berikut data hasil uji hipotesa dapat dilihat pada tabel 7.

Tabel 7 Uji Anova Kemampuan Latihan Emosi Parenting

\begin{tabular}{lccccc}
\hline & Sum of Squares & Df & Means Square & F & Sig. \\
\hline Between Groups & 13.638 & 1 & 13.638 & 30.775 & 0,0000 \\
Within Groups & 12.409 & 28 & 0.443 & & \\
Total & 26.047 & 29 & & & \\
\hline
\end{tabular}

Berdasarkan tabel 7 diperoleh hasil uji One Way Anova untuk uji hipotesa yaitu nilai $\mathrm{F}_{\text {hitung }}$ sebesar 27,981 dan nilai signifikansi sebesar 0,000. Sedangkan nila $\mathrm{F}_{\text {tabel }}$ 3,16 dengan taraf $5 \%$. $\mathrm{F}_{\text {hitung }}$ lebih besar dari pada $\mathrm{F}_{\text {tabel }}$, yaitu $30.775>3,16$. Sehingga, $\mathrm{H}_{o}$ ditolak dan $\mathrm{H}_{a}$ diterima yang artinya bahwa panduan Aneuk Meutuah efektif dalam latihan emosi parenting terhadap regulasi emosi anak usia 3-4 tahun pada PAUD di Puskesmas Kecamatan Baitussalam Aceh Besar.

Ringkasan deskripsi data skor pre-test, post-test, dan gain score kemampuan penerapan antara panduan Anuek Meutuah dan modul parenting dalam latihan emosi parenting disajikan pada Tabel 8.

Tabel 8 Rekapitulasi Hasil Perhitungan Skor Pre-Test, Post-Test, dan Gain Score kemampuan penerapan latihan emosi parenting untuk masing-masing media

\begin{tabular}{|c|c|c|c|c|c|c|}
\hline \multirow[t]{2}{*}{ Statistik } & \multicolumn{3}{|c|}{ PANDUAN ANEUK MEUTUAH } & \multicolumn{3}{|c|}{$\begin{array}{c}\text { MODUL PARENTING } \\
\text { (KEMDIKBUD) }\end{array}$} \\
\hline & $\begin{array}{l}\text { Pre- } \\
\text { Test }\end{array}$ & $\begin{array}{l}\text { Post- } \\
\text { Test }\end{array}$ & $\begin{array}{l}\text { Gain } \\
\text { Score }\end{array}$ & $\begin{array}{l}\text { Pre- } \\
\text { Test }\end{array}$ & $\begin{array}{l}\text { Post- } \\
\text { Test }\end{array}$ & $\begin{array}{l}\text { Gain } \\
\text { Score }\end{array}$ \\
\hline $\mathrm{N}$ & 15 & 15 & 15 & 15 & 15 & 15 \\
\hline Mean & 66,6667 & 73,733 & 7,067 & 66,267 & 68,333 & 2,05 \\
\hline Standar & 3,94 & 2,3442 & $-0,13968$ & 3,369 & 3,266 & $-0,10666$ \\
\hline Deviation & & & & & & \\
\hline Varians & 5,670 & 57,964 & 0,01951 & 3,753 & 28,302 & 0,01138 \\
\hline Range & 11 & 11 & 0 & 12 & 9 & -3 \\
\hline Minimum & 62 & 69 & 7 & 62 & 648 & 2 \\
\hline Maximum & 73 & 78 & 5 & 74 & 73 & -1 \\
\hline
\end{tabular}

Keterangan

PAM : Panduan Aneuk Meutuah

MKD : Modul Parenting(Kemdikbud)

Berdasarkan Tabel.5.21 dapat dijelaskan: 1)rata-rata gain score orang tua pada kelompok perlakukan lebih besar dibandingkan kelompok kontrol, yaitu 7,067 $>2,05$. Hal ini berarti bahwa orang tua yang mempraktikan panduan Aneuk Meutuah memperoleh peningkatan rata- rata skor kemampuan latihan emosi parenting yang lebih baik dibandingkan dengan orang tua yang menggunakan modul parenting.

\section{Pembahasan}

Berdasarkan hasil analisis data diperoleh bahwa besarnya koefisien beda mean dengan $\mathrm{t}$ sebesar 4,093 dengan $\mathrm{p}$ sebesar $0,001(\mathrm{p}<0,05)$ yang berarti sangat signifikan. Panduan Aneuk Meutuah dapat meningkatkan latihan emosi parenting orang tua yaitu kemampuan latihan emosi parenting orang tua lebih baik dibandingkan sebelum menggunakan panduan 
Aneuk Meutuah. Selain itu, efektifitas panduan Aneuk Meutuah didukung data hasil nilai partial eta squared $\left(\eta^{2}\right.$ ) diketahui besarnya 23,7\% artinya panduan Aneuk Meutuah dalam latihan emosi parenting memberikan sumbangan sebesar $23,7 \%$ bagi orang tua dalam merefleksikan emosi kepada emosi anak usia 3-4 tahun .

Temuan empiris dari tabel.5.21 menunjukkan bahwa orang tua yang berada pada kelompok eksperimen yang menggunakan Panduan Aneuk Meutuah dalam Latihan emosi parenting memiliki rata-rata kemampuan dan pernambahan ketrampilan yang lebih besar dibandingan dengan orang tua pada kelompok kontrol. Hal tersebut dapat disimpulkan bahwa kemampuan orang tua pada kelompok eksperimen sebesar 73,73 lebih besar dari pada orang tua pada kelompok kontrol yang memiliki rata-rata nilai 68,33.

Pelaksanaan pada penelitian ini menggunakan panduan Aneuk Meutuah yang dirancang untuk mengembangkan kemampuan latihan emosi parenting orang tua sesuai dengan lima langkah latihan emosi parenting. Latihan emosi parenting merupakan suatu bentuk perilaku yang didasari oleh kesadaran atau kematangan emosi diri individu. Selain itu, latihan emosi parenting juga merupakan upaya orang tua untuk memahami emosi anak usia 3-4 tahun. Kemudian orang tua mengajarkan mengenal, menentukan, berekspresi, dan merespon kepada anak usia 3-4 tahun dalam menghadapi emosi negatif (Gross, 2014 dan Kurniasih et al., 2021). Sebagai gambaran dapat dilihat pada gambar 1.

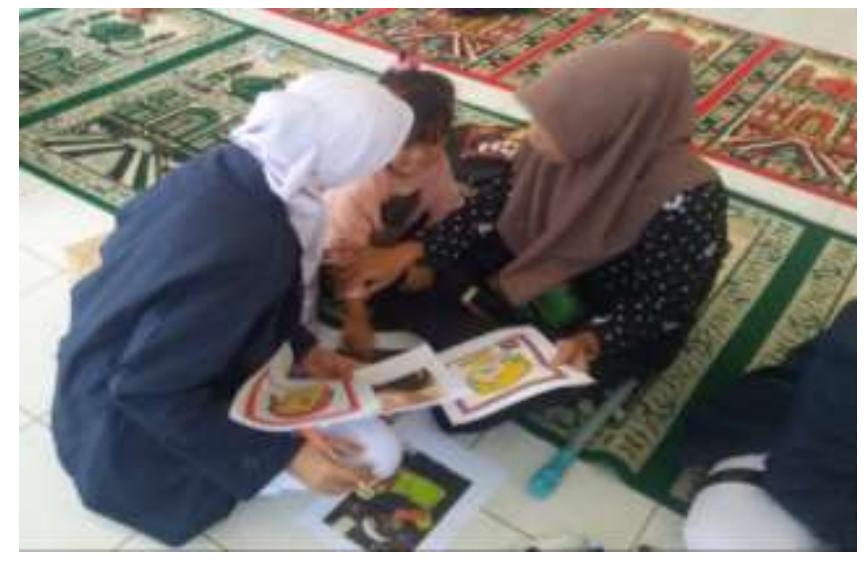

Gambar 1 Penerapan latihan emosi parenting (orang tua membantu mengenalkan emosi pada anak usia 3-4 tahun)

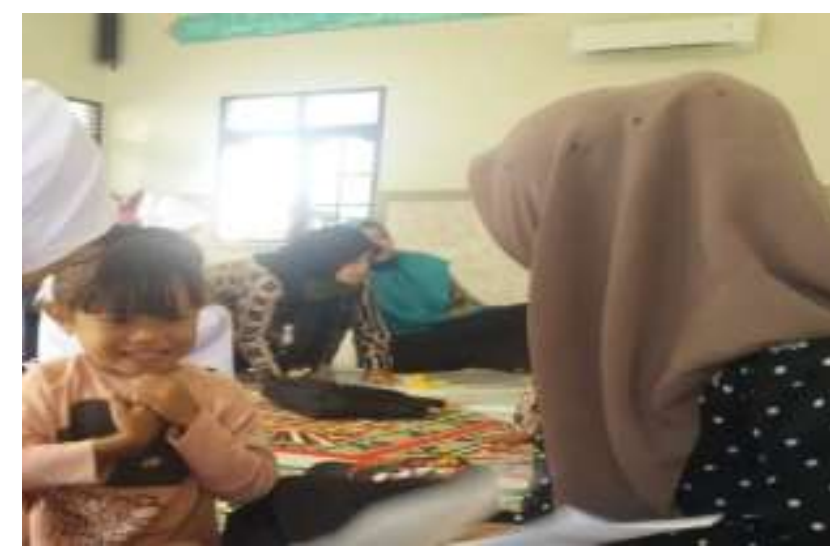

Gambar 3 Penerapan latihan emosi parenting (orang tua melakukan ekspresi emosi positif pada anak usia 3-4 tahun )

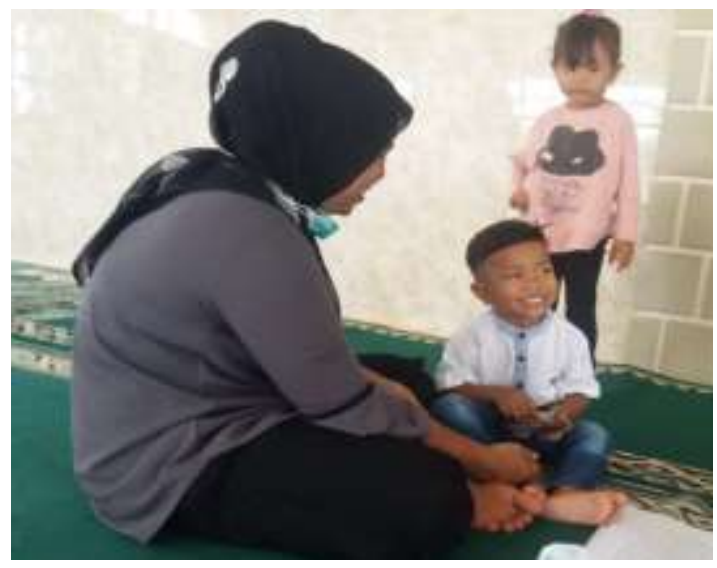

Gambar 2 Penerapan latihan emosi parenting (orang tua membantu menentukan emosi pada anak usia 3-4 tahun )

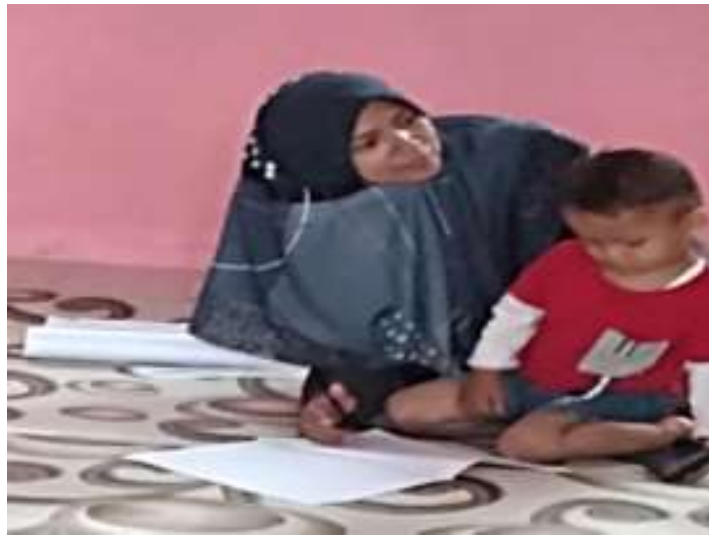

Gambar 4 Penerapan Latihan emosi parenting (orang tua merespon emosi positif pada emosi negatif anak usia 3-4 tahun) 
Adapun target latihan emosi parenting adalah respon emosi positif orang tua terhadap emosi anak sehingga meningkatkan pemahaman anak usia dini dengan berbagai bentuk emosi. Pernyataan tersebut didukung oleh peneliti lain yang mendefinisikan respon orang tua sebagai bentuk sensitifitas orang tua dalam memberikan tanggapan terhadap emosi anak usia dini secara langsung (Shaw et al., 2006). Didukung, hasil penelitian lain yang mengemukakan bahwa latihan emosi mampu meningkatkan pengetahuan dan ketrampilan orang tua dalam merespon momen emosi anak usia 4 - 6 tahun (Kurniasih et al., 2021).

Orang tua mampu menebak dengan benar jenis emosi yang ditampilkan pada anak usia 3-4 tahun, memanfa'atkan momen emosi pada anak usia dini, dan mendengarkan keluhan perasaan anak dengan penuh empati (Lihat Gambar.2 diatas). Selanjutnya, anak usia 3-4 tahun merefelsikan ekspresi emosi positif dan menyatakan perasaannya secara verbal (Lihat Gambar.3).

Temuan penelitian ini memperlihatkan bahwa Panduan Aneuk Metuah untuk latihan emosi parenting merupakan suatu media stimulus yang efektif. Media ini dapat digunakan oleh orang tua sebagai acuan dalam menjalankan perannya sebagai pengatur eksternal emosi anak. Pada akhir kegiatan, orang tua dapat mendemontrasikan dalam merefleksikan emosi positif yang tepat kepada emosi anak usia 3-4 tahun. Temuan dilokasi penelitian juga menggambarkan bahwa setelah menggunakan Panduan Aneuk meutuah dalam latihan emosi parenting, orang tua selalu tetap berusaha untuk sadar emosi dan menempatkan dirinya untuk selalu memahami emosi anak usia 3-4 tahun. Keadaan tersebut, orang tua dapat lebih fokus berespon terhadap setiap tampilan ekspresi emosi positif anak bukan pada masalah yang dimiliki anak usia 3-4 tahun. Orang tua sebagai role model dituntut mampu memodulasi dorongan emosinya sehingga meningkatkan kemampuan adaptasi dengan lingkungan sekitarnya. Ekspresi emosi orang tua tersebut dapat dijadikan pengalaman awal bagi anak berekspresi emosi. Anak usia 3-4 tahun memiliki kemampuan merespon emosi dengan cepat sesuai tuntutan lingkungan yang secara sosial dapat diterima (Lihat Gambar.4 dibawah) Hal tersebut didukung oleh hasil penelitian yang mengemukakan bahwa emosi dasar yang sering dialami oleh anak usia 3-4 tahun diantaranya senang, sedih, marah, dan takut (Nurmelly, 2005; Bata, 2020; Shaver et al., 1987; Denham et al., 2003).

Panduan Aneuk Meutuah menuntun kepada setiap subjek penelitian untuk mengikuti petunjuk lima langkah-langkah melakukan latihan emosi parenting. Subjek peneliti berupaya menvalidasi ekspresi emosi, mencari peluang berkomunikasi efektif, bersikap empati, melabel emosi diri, dan membantu anak berekspresi emosi positif sesuai dengan kondisi. Selanjutnya, orang tua mempraktekkan langsung latihan emosi parenting melalui kegiatan rutin harian anak usia 3-4 tahun. Sebagai contoh anak yang tidak percaya diri, orang tua dapat mengatakan "Bunda bangga dengan diri kamu dan pasti kamu juga bangga dengan dirimu sendiri" (Lihat gambar 5)

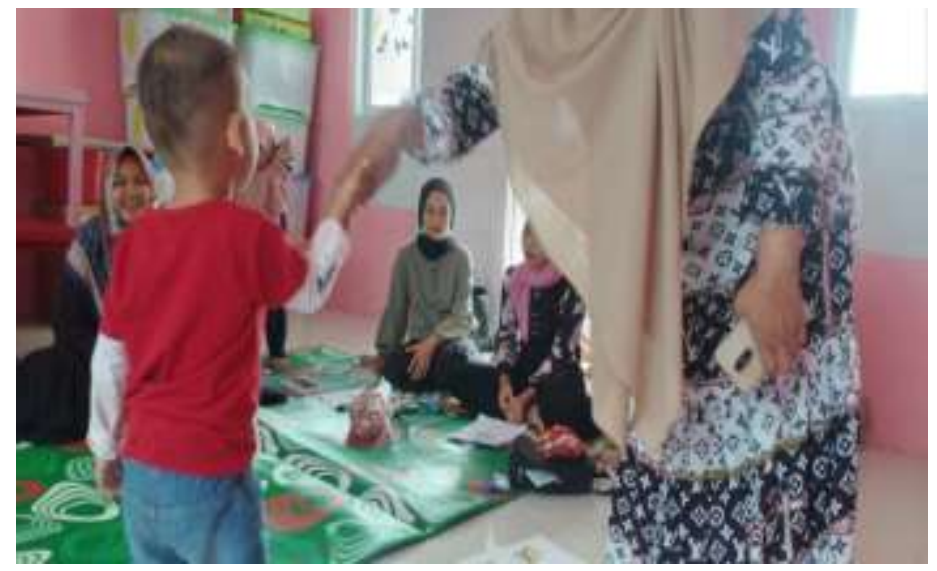

Gambar.5: Penerapan Latihan emosi parenting (praktik langsung latihan emosi parenting pada anak tidak percaya diri) 
Pada gambar 5, orang tua berekspresi emosi senang dengan bersikap tulus dengan asumsi peneliti bahwa anak usia 3-4 tahun akan selalu menanggapi setiap bentuk pujian. Latihan emosi parenting dengan Panduan Aneuk Meutuah ini juga merupakan suatu cara membangun kesesuaian refleksi emosi orang tua dengan emosi anak usia 3-4 tahun. Hal tersebut, didukung oleh Thompson ( 2011) yang mengemukakan bahwa latihan emosi parenting akan meningkat bersamaan dengan bertambahnya kemampuan refleksi emosi pada anak usia dini. Selain itu, bahasa (bentuk pujian) sangat berperan dalam memfasilitasi kapasitas anak untuk memahami, mengutarakan, merefleksikan, dan mengatur emosi pada diri sendiri (Brownell et al., 2009). Disamping itu, hubungan interpersonal anak dengan teman sebaya juga menjadi hal yang penting perlu diperhatikan dalam mengembangkan ketrampilan kemampuan regulasi emosi anak usia 3-4 tahun(Lagattuta, 2014). Kedua petunjuk tersebut, orang tua dapat menggunakan sebagai indikator capaian latihan emosi parenting oleh karena komitmen dan emosi anak dapat mencerminkan dasar kepatuhan terhadap perintah orang tua mereka(Ellis et al.,2014; Allen, 2015; dan Afrida, 2017)

Temuan-temuan penelitian ini juga didukung oleh beberapa hasil penelitian yang menunjukkan bahwa modul pelatihan dan manual training tentang latihan emosi parenting dapat menigkatkan capaian kemampuan ekspresi emosi orang tua (Nurjanah et al., 2019) dan meningkatkan kemamampuan manajemen emosi anak (Ediati, 2019).

Berdasarkan hal tersebut, Panduan Aneuk Meutuah dapat dijadikan sebagai salah satu media belajar dalam latihan emosi parenting untuk mengembangkan kemampuan sadar emosi, mengontrol emosi dan mengelola emosi bagi orang tua. Selain itu, panduan Aneuk Meutuah dapat memberikan pencerahan pengetahuan tentang latihan emosi parenting dan pengalaman mempraktikan langsung dengan mengikuti lima langkah latihan emosi parenting mulai validasi emosi, berkomunikasi efektif, bersikap empati, melabel emosi diri, dan membantu anak berekspresi emosi positif. Bagi peneliti selanjutnya yang tertarik pada penelitian yang sama, dapat melakukan penelitian dengan subyek yang lebih besar dan karakteristik demografis subyek yang lebih bervariasi. Hal ini dapat dijadikan pembanding, apakah hasil penelitian yang dihasilkan nanti memiliki kesamaan atau ada perbedaan. Pada akhirnya nanti jika semakin banyak hasil penelitian yang sama, maka kesimpulan penelitian ini dapat melengkapi penelitian yang akan datang untuk menarik penelitian yang lebih umum.

\section{SIMPULAN}

Latihan emosi parenting dengan Panduan Aneuk Meutuah ini mampu meningkatkan kesesuaian emosi positif orang tua dengan emosi anak pada siswa TK Kelompok B. di Kecamatan Baitussalam Aceh Besar. Hal ini dapat dibuktikan dengan terdapat perbedaan kemampuan refleksi emosi antara orang tua pada kelompok perlakuan dan orang tua pada kelompok kontrol. Pada kelompok perlakuan, ekspresi emosi orang tua lebih berkualitas dalam bersikap empati dan berkomunikasi dibandingkan dengan kelompok kontrol. Harapan peneliti, orang tua agar dapat lebih inovatif dan kreatif dalam memilih bahasa untuk mengkomunikasikan ekspresi emosi positifnya kepada anak usia 3-4 tahun sehingga terciptanya kesesuaian ekspresi emosi antara emosi orang tua tua dan emosi anak.

\section{UCAPAN TERIMA KASIH}

Terima kasih peneliti ucapkan kepada Allah SWT atas limpahan rahmat-Nya dan petunjuknya sehingga peneliti dapat selesai melaksanakan penelitian dan menyelesaikan kegiatan penelitian sesuai dengan jadwal yang telah ditentukan. Selanjutnya, peneliti ucapkan terima kasih kepada semua pihak yang terlibat, yaitu Kepala Puskesmas Kecamatan Baitussalam, Ketua PAUD Bungong Reudeup gampong Miruek Lam Reudeup, Ketua PAUD/Twk. Abdul Aziz Gampong Kecamatan Baitussalam Kabupaten Aceh Besar, orang tua/subyek penelitian atas pastisipasi aktif dan kesempatan yang telah diberikan serta 
tersedianya lokasi penelitian sehingga kegiatan penelitian selesai tepat pada waktunya. Semoga, semua amal ibadah mereka diterima oleh Allah swt.

\section{DAFTAR PUSTAKA}

Achenbach, T. M., Edelbrock, C., \& Howell, C. T. (1987). Empirically based assessment of the behavioral/emotional problems of 2- and 3- year-old children. Journal of Abnormal Child Psychology, 15(4), 629-650. https:// doi.org/10.1007/BF00917246

Affrida, E. N. (2017). Jurnal obsesi. Jurnal Obsesi : Jurnal Pendidikan Anak Usia Dini, 1(2), 97104. https://obsesi.or.id/index.php/obsesi/article/view/20/19 https:// doi.org/10.31004/obsesi.v1i1.28

Allen, L. R. M. K. E. (2015). Profil Perkembangan: Pra-Kelahiran Melalui Masa Remaja.

Anders, Y., Grosse, C., Rossbach, H. G., Ebert, S., \& Weinert, S. (2013). Preschool and primary school influences on the development of children's early numeracy skills between the ages of 3 and 7 years in Germany. School Effectiveness and School Improvement, 24(2), 195-211. https:// doi.org/10.1080/09243453.2012.749794

Aubrey, C., David, T., Godfrey, R., \& Thompson, L. (2000). Early Childhood Educational Research - Issues in methodology and ethics. In Journal of Educational Psychology (Vol. 29, Issue 8).

Bata, J. (2020). \# AkuGalau: Korpus Bahasa Indonesia untuk Deteksi Emosi dari Teks \# AkuGalau: Korpus Bahasa Indonesia untuk Deteksi Emosi dari Teks Program Studi Sistem informasi , Fakultas Teknik Universitas Katolik Indonesia Atma Jaya, Jakarta. June.

Besar, B. A. (2018). Kecamatan Baitussalam aceh besar (BPS Aceh Besar (ed.)).

Brownell, C. A., Svetlova, M., \& Nichols, S. (2009). To share or not to share: When do toddlers respond to another's needs? Infancy, 14(1), 117-130. https:// doi.org/10.1080/15250000802569868

Denham, S. A., Blair, K. A., Demulder, E., Levitas, J., Sawyer, K., Auerbach-Major, S., \& Queenan, P. (2003). Preschool Emotional Competence: Pathway to Social Competence? Child Development, 74(1), 238-256. https://doi.org/10.1111/1467-8624.00533

Ediati, A. (2019). Anak tangguh 8-10.

Ellis, B. H., Alisic, E., Reiss, A., Dishion, T., \& Fisher, P. A. (2014). Emotion Regulation Among Preschoolers on a Continuum of Risk: The Role of Maternal Emotion Coaching. Journal of Child and Family Studies, 23(6), 965-974. https://doi.org/10.1007/s10826-013-9752$\underline{\mathrm{Z}}$

Graziano, P. A., Reavis, R. D., Keane, S. P., \& Calkins, S. D. (2007). The role of emotion regulation in children's early academic success. Journal of School Psychology, 45(1), 3 19. https://doi.org/10.1016/i.jsp.2006.09.002

Gross, J. J. (2014). Handbook of emotion regulation (2nd ed.). New York, NY, US: Guilford Press.

Hake, R. R. (1999). Analyzing Change/Gain Scores. Edukimia, 1(1), 1-4.

Hasinuddin, M., \& Fitriah. (2016). Modul Anticipatory Guidance Merubah Pola Asuh Orang Tua Yang Otoriter Dalam Stimulasi Perkembangan Anak. Jurnal Ners, 6(1), 50-57. https://e-journal.unair.ac.id/JNERS/article/viewFile/3965/2678

Hayati, D. J., \& Suparno, S. (2020). Efektivitas Buku Cerita Bergambar pada Keberhasilan Toilet Training Anak Usia 3-4 Tahun. Jurnal Obsesi : Jurnal Pendidikan Anak Usia Dini, 4(2), 1041. https://doi.org/10.31004/obsesi.v4i2.498

Izard, C. E. (2007). Basic Emotions, Natural Kinds, Emotion Schemas, and a New Paradigm. Perspectives on Psychological Science, 2(3), 260-280. https://doi.org/10.1111/j.17456916.2007.00044.x

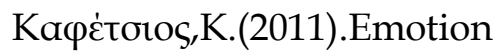

course.

190-202.

http://psychology.soc.uoc.gr/kafetsios/Emotion.htm 
Kurniasih, K., Supena, A., \& Nurani, Y. (2021). Peningkatan Kepercayaan Diri Anak Usia Dini melalui Kegiatan Jurnal Pagi. Jurnal Obsesi : Jurnal Pendidikan Anak Usia Dini, 5(2), 2250-2258. https:// doi.org/10.31004/obsesi.v5i2.1109

Lagattuta, K. H. (2014). Anak-anak dan emosi, wawasan baru ke dalam ilmu afektif perkembangan (Vol. 26). Karger, Tahun: 2014.

Louis Cohen, Lawrence Manion, K. M. (2018). Metode Penelitian dalam Pendidikan.

Maddux JE. (1995). Adaptation, and Adjustment the Plenum Series in.

Mashburn, A. J., Pianta, R. C., Hamre, B. K., Downer, J. T., Barbarin, O. A., Bryant, D., Burchinal, M., Early, D. M., \& Howes, C. (2008). Measures of classroom quality in prekindergarten and children's development of academic, language, and social skills. Child Development, 79(3), 732-749. https:// doi.org/10.1111/j.1467-8624.2008.01154.x

Mayasari, D., Istirahayu, I., \& Mawarni, K. (2020). Hubungan Pola Asuh Orang Tua Terhadap Kemandirian Anak Usia Dini Di TK Negeri Pembina Singkawang Timur. Journal of Educational Review and Research, 3(2), 111. https://doi.org/10.26737/jerr.v3i2.2155

Nurjanah, N., Miranti, I., \& Dwiastuty, N. (2019). Manajemen Emosi pada Anak Usia Dini. $\begin{array}{llll}\text { Jurnal PkM Pengabdian Kepada Masyarakat, } 259 . & \text { 2(03), }\end{array}$ https://doi.org/10.30998/jurnalpkm.v2i03.4588

Nurmelly, D. N. (2005). Mengetahui Tingkat Emosi Seseorang. 1.

Of, S., Health, N., Services, H., Office, I. P. C., Of, B., \& Intervention, E. (2018). State Of Nevada Health And Human Services Social-Emotional Practices Module Module 6. June.

Parenting, E. I. N. (n.d.). Emotions in parenting - Greenberg Emotions_in_parenting.pdf. https://connect.ubc.ca/bbcswebdav/pid-2970809-dt-content-rid-

13239101_1/courses/SIS.UBC.CNPS.514.001.2015W1.51548/Greenberg

Emotions_in_parenting.pdf

Pianta, R. C., Belsky, J., Vandergrift, N., Houts, R., \& Morrison, F. J. (2008). Classroom effects on children's achievement trajectories in elementary school. American Educational Research Journal, 45(2), 365-397. https://doi.org/10.3102/0002831207308230

Raikes, H. A., \& Thompson, R. A. (2006). Family emotional climate, attachment security and young children's emotion knowledge in a high risk sample. British Journal of Developmental Psychology, 24(1), 89-104. https://doi.org/10.1348/026151005X70427

Roopnarine, J. L., \& Gielen, U. P. (2005). Post-modern Families. Families in Global Perspective. http://www.longman.ch/download/media/9780205335749_SP.pdf

Saputra, H., Al Auwal, T. M. R., \& Mustika, D. (2017). Pembelajaran Inkuiri Berbasis Virtual Laboratory Untuk Meningkatkan Kemampuan Literasi Sains Mahasiswa Calon Guru Pendidikan Fisika Universitas Samudra. Jurnal IPA \& Pembelajaran IPA, 1(2), 143-148. https://doi.org/10.24815/jipi.v1i2.9688

Shaver, P., Schwartz, J., Kirson, D., O'Connor, C., \& O'connor, G. (1987). ATTITUDES AND SOCIAL COGNITION Emotion Knowledge: Further Exploration of a Prototype Approach. Journal of Personality and Social Psychology, 52(6), 1061. https://s3.amazonaws.com/academia.edu.documents/41383936/Emotion_Knowled ge_Further_Exploration_of20160121-10163-

jqeiwm.pdf?AWSAccessKeyId=AKIAIWOWYYGZ2Y53UL3A\&Expires=1535498321\& Signature=UFgdJrboH3MAzQP8\%2FcGw8Chr7HM\%3D\&response-contentdisposition $=$ inlin

Shaw, D. S., Sherrill, J., \& Huffman, D. (2006). Responsivity to Offspring ' s Expression of Emotion Among Childhood-Onset Depressed Mothers David Obrosky and Maria Kovacs. 35(4), 490-503. https://doi.org/10.1207/s15374424jccp3504_1

Thompson, R. A. (2011). Emotion and emotion regulation: Two sides of the developing coin. Emotion Review, 3(1), 53-61. https://doi.org/10.1177/1754073910380969 https://doi.org/10.1177/1754073910380969

Wahyuningsih, H., \& Indonesia, U. I. (2019). Pelatihan Emotion Coaching Untuk Meningkatkan. 11, 67-78. https:// doi.org/10.20885/intervensipsikologi.vol11.iss2.art1 